\title{
MEDIA MODIFIKASI TEPUNG IKAN TERI, RUMPUT LAUT, UBI JALAR UNGU DAPAT MEMPERCEPAT PERTUMBUHAN MYCOBACTERIUM TUBERCULOSIS
}

\author{
Rohmi $^{1}$, Maruni Wiwin Diarti ${ }^{1 凶}$, Yunan Jiwintarum $^{2}$ \\ ${ }^{1}$ Prodi D.IV Jurusan Analis Kesehatan Poltekkes Kemenkes Mataram \\ ${ }^{2}$ Prodi D.III Jurusan Analis Kesehatan Poltekkes Kemenkes Mataram
}

\section{ARTICLE INFO \\ Article history \\ Submitted : 2020-09-07 \\ Revised : 2021-05-29 \\ Accepted : 2021-07-02 \\ Keywords: \\ Fish meal \\ Mycobacterium tuberculosis \\ Purple sweet potato \\ Seaweed}

\section{Kata Kunci: \\ Tepung ikan teri Mycobacterium tuberculosis Ubi jalar ungu Rumput laut}

\begin{abstract}
The common growth medium used to growth M. Tuberculosis is Lowenstein-Jensen. Examination by culture method has several disadvantages: the incubation period is too long to calculate the growth of $M$. Tuberculosis that reaches 8 weeks to be able to declare negative results. Aims is research to know the result of growth rate and growth rate of $M$. Tuberculosis from combination formulation media of local food of sea fish meal (Stolephorussp), Purple Sweet Potato flour (Ipomoea batatas) and Euchema Spinosum Seaweed flour called TURLM media (Grass Sweet Teri Sea Medium). Research is an exploratory research in laboratory, using three forms of TURLM media formulation and Loweinstein-Jensen media comparator, data collected in the form of growth speed and fertility rate of $M$. Tuberculosis, descriptive data analysis. The results showed that TRULM media formulas 1,2 , and 3 can show the growth of $M$. Tuberculosis coloccus of ATCC 25177, with the best growth rate in TURLM Formula 3 medium which is similar to LJ control media. Fertility growth rate of M. Tuberculosis ATCC 25177 TURLM medium The best formula is TRULM Formula 3 whose fertility rate is equal to growth in Loweinstein-Jensen (LJ) control media. The conclusion of this research is that TURLM formula 3 media can be used as growth media of $M$. Tuberculosis which can accelerate the growth of M. Tuberculosis and show good fertility rate.

Media pertumbuhan yang umum digunakan untuk menumbuhkan M. Tuberculosis adalah Lowenstein-Jensen. Pemeriksaan dengan metode kultur memiliki beberapa kelemahan yaitu masa inkubasi yang terlalu panjang untuk menghitung pertumbuhan $M$. tuberculosis yang mencapai 8 minggu untuk bisa menyatakan hasil negatif. Penelitian ini bertujuan untuk mengetahui hasil kecepatan pertumbuhan dan angka pertumbuhan M. Tuberculosis dari media formulasi kombinasi pangan lokal tepung ikan terilaut (Stolephorus sp), tepung Ubi Jalar Ungu (Ipomoea batatas) dan tepung Rumput Laut Euchema Spinosum yang disebut dengan media TURLM (Teri Ubi Rumput Laut Medium). Penelitian ini merupakan penelitian eksploratorik di laboratorium, dengan menggunakan tiga bentuk formulasi media TURLM dan pembanding media Loweinstein-Jensen, data yang dikumpulkan berupa kecepatan pertumbuhan dan angka kesuburan M. Tuberculosis, analisis data secara deskriptif. Hasil penelitian menunjukkan bahwa media TRULM formula 1, 2, dan 3 dapat menunjukkan adanya pertumbuhan koloni M. Tuberculosis ATCC 25177, dengan kecepatan pertumbuhan yang paling baik pada media TURLM Formula 3 yang sama dengan media kontrol LJ. Angka kesuburan pertumbuhan M. Tuberculosis ATCC 25177 media TURLM formula yang paling baik adalah TRULM Formula 3 yang angka kesuburannya sama dengan pertumbuhan pada media kontrol Loweinstein-Jensen (LJ). Kesimpulan dari penelitian ini bahwa media TURLM formula 3 dapat digunakan sebagai media pertumbuhan $M$. Tuberculosis yang dapat mempercepat pertumbuhan M. Tuberculosis dan menunjukkan angka kesuburan yang baik.
\end{abstract}

Corresponding Author:

Maruni Wiwin Diarti

Prodi D.IV Jurusan Analis Kesehatan Poltekkes Kemenkes Mataram

Telp. 082236371510/ 087865117411

Email: maruniwiwindiarti@yahoo.com

\section{PENDAHULUAN}

Kejadian tuberkulosis disebabkan oleh Mycobacterium Tuberculosis, sebagian besar kuman TB menyerang paru, tetapi dapat juga mengenai organ tubuh lainnya. Pewarnaan yang berguna untuk melihat morfologi bakteri ini 
adalah pewarnaan tahan asam, misalnya pewarnaan Zeihl-Neelsen ataupun Kinyon Gabbet (Crofton, Horne, \& Miller, 2002). Media pertumbuhan yang umum digunakan untuk menumbuhkan Mycobacterium Tuberculosis adalah Lowenstein-Jensen menggunakan malasit green untuk menghambat bakteri lain kemudian memodifikasi dengan citrat dan phosphat. Komposisi dari asam fatty dan protein esensial untuk metabolisme bakteri. Glyserol bersumber dari karbon dan energi yang dibutuhkan untuk tipe human tubercle bacillus daripada bovine tipe. Asparagin dan RNA ditumbuhkan untuk menyediakan sumber nitrogen dan stimulant pertumbuhan koagulasi dari albumin telur perlu diperhatikan selama proses mencampurkan telur dengan media, jangan dalam keadaan panas karena dapat mengakibatkan kematangan pada telur. Inspirasi menyediakan medium solid untuk inokulasi kultur spesimen dari mikroba selalu berisi campuran kontaminasi mikroorganisme sehingga mengharuskan menggunakan antibiotic selektif di dalam media untuk isolasi. Asam nalidixic menghambat bakteri gram (-). Lincomycin menghambat bakteri gram (+). Cycloheximide menekan jamur saprofit (Crofton et al., 2002).

Diagnosa tuberculosis sampai saat ini masih ditegakkan berdasarkan pemeriksaan sputum secara mikroskopis langsung dengan pewarnaan Bakteri Tahan Asam (BTA), dilanjutkan dengan pemeriksaan kultur untuk konfirmasi identifikasi yang keperluan uji sensitivity antibiotika. Umumnya kultur biakan menggunakan media Loewenstein Jensen (LJ). Pemeriksaan dengan metode kultur memiliki beberapa kelemahan yaitu masa inkubasi yang terlalu panjang untuk menghitung pertumbuhan $M$. Tuberculosis yang mencapai 8 minggu untuk bisa menyatakan hasil negatif. Komposisi media LJ yang relatif menggunakan bahanbahan yang mahal dan memerlukan pembuatan yang khusus yang memerlukan ketelitian (Patrick R. Murray \& Rosenthal, 2007). Beberapa penelitian terdahulu yang mencari bahan alternatif untuk pertumbuhan $M$. tuberculosis antara lain penelitian Srigede, L., Zaetun, S., dan Getas, I. W. (2013) yang membuktikan bahwa Mycobacterium Tuberculosis dapat tumbuh pada media Agar Nutrien dengan penambahan tepung cacing (Lumbricus rubellous), penelitian Munawaroh, A. L.dkk (2015) yang berhasil membuat media
Coco blood malachite green (CBM) yaitu media kultur dengan komposisi air kelapa muda, malachite green, darah domba, agar darah, dan gliserol dengan hasil nilai spesifitas 96,6\% dan sensitivitas $100 \%$ dan media CBM lebih cepat dan sensitif daripada LJ, namun LJ lebih spesifik daripada CBM. Penelitian Maria, N dan Rosnita, S (2018) membuktikan bahwa Mycobacterium Tuberculosis tumbuh pada base agar darah yang ditambahkan air kelapa dengan konsentrasi $100 \%$. Pertumbuhan terjadi dengan lama inkubasi 14 hari pada suhu $28^{\circ} \mathrm{C}$ dan $37^{\circ} \mathrm{C}$. Belum adanya informasi secara ilmiah yang mengeksplorasi formulasi bahan alami dari campuran tepung ikan teri, ubi jalar ungu dan rumput laut sebagai media alternatif pertumbuhan $M$. Tuberculosis terutama terhadap kecepatan pertumbuhan koloni dan angka kesuburan pertumbuhan $M$. Tuberculosis yang merupakan kebaharuan dari hasil penelitian ini.

Permasalahan dari kelemahan media kultur ini mendasari pencarian bahan-bahan alam sebagai bahan alternatif yang dapat digunakan untuk pertumbuhan $M$. Tuberculosis, dengan membuat analisis formula untuk eksplorasi formula pertumbuhan $M$. Tuberculosis yang bersifat eksperimen di laboratorium menggunakan kombinasi tepung ikan teri laut (Stolephorussp), tepung Ubi Jalar Ungu (Ipomoea batatas) dan tepung Rumput Laut Euchema Spinosum yang diberi nama media TURLM (Teri Ubi Rumput Laut Medum). Kandungan kimia dari rumput laut Eucheuma spinosum adalah keraginan (65\%), protein, karbohidrat, lemak, serat kasar, air dan abu. Keraginan merupakan polisakarida tersulfatkan dimana kandungan ester sulfatnya adalah 28 - 35\% (Horboruw, 2012; Suparmi \& Sahri, 2009).

Kandungan nutrisi ubi jalar ungu lebih tinggi bila dibandingkan ubi jalar varietas lain, terutama kandungan lisin, $\mathrm{Cu}, \mathrm{Mg}, \mathrm{K}, \mathrm{Zn}$ ratarata 20\%. (Kumalaningsih, 2007; Hardoko Liana H, dan Tagor, M. 2010). Kandungan nutrisi/gizi pada ikan teri: banyaknya ikan teri yang diteliti (food weight) $=100 \mathrm{gr}$, bagian ikan teri yang dapat dikonsumsi (Bdd/Food Edible) $=100 \%$ kandungannya adalah energi ikan teri $=74 \mathrm{kkal}$, jumlah kandungan protein ikan teri $=$ 10,3 gr, lemak ikan teri $=1,4$ gr, karbohidrat ikan teri $=4,1 \mathrm{gr}$, kalsium ikan teri $=972 \mathrm{mg}$, fosfor ikan teri $=253 \mathrm{mg}$, zat besi ikan teri $=$ $3,9 \mathrm{mg}$, Vitamin A ikan teri $=42 \mathrm{IU}$, Vitamin 
B1 ikan teri $=0,24 \mathrm{mg}$, Vitamin $\mathrm{C}$ ikan teri $=0$ mg. (Fahmi, A 2012; Wiwit, P. 2015).

Penelitian ini bertujuan untuk mengetahui hasil kecepatan pertumbuhan dan angka pertumbuhan $M$. Tuberculosis ATCC 25177 dari media formulasi kombinasi pangan lokal tepung ikan terilaut (Stolephorus sp), tepung Ubi Jalar Ungu (Ipomoea batatas) dan tepung Rumput Laut Euchema Spinosum yang disebut dengan media TURLM (Teri Ubi Rumpu Laut Medium). Eksplorasi formula pangan lokal yang dalam penelitian ini diharapkan memberikan hasil pertumbuhan $M$. tuberculosis yang baik, lebih cepat, murah dan menghasilkan nilai positivitas yang tinggi.

\section{METODE PENELITIAN}

\section{Proses Sampling}

Besar unit penelitian yang dibutuhkan untuk mengetahui kemampuan formula modifikasi media pertumbuhan $M$. Tuberculosis yang terbuat dari tepung ikan teri laut, tepung ubi jalar ungu dan tepung rumput laut dengan penambahan gliserol dalam formula media 1, formula media 2 dan formula media 3 adalah sebanyak 12 unit ( 3 perlakuan formula x 4 kali ulangan). Teknik pengambilan sampel menggunakan teknik Non Random Purposive Sampling bentuk tepung.

\section{Prosedur Penelitian}

Pembuatan Tepung Ikan Teri Laut (Stolephorus sp), ikan teri kering digiling halus kemudian diayak dan disimpan dalam botol tertutup rapat. Pembuatan Tepung Ubi Jalar Ungu (Ipomoea batatas), ubi jalar ungu dikupas dan dipotong kecil-kecil, dikering anginkan pada panas matahari selama 3 hari. Ubi jalar ungu yang sudah kering digiling halus dan diayak, kemudian disimpan dalam botol tertutup rapat. Pembuatan Tepung Rumput Laut Euchema Spinosum, rumput laut digiling halus, dikering anginkan sampai kering dan diayak. Serbuk tepung disimpan dalam botol tertutup rapat.

Pembuatan modifikasi Media TURLM (Teri Ubi Rumput Laut Medium) untuk Pertumbuhan M. Tuberculosis adalah media modifikasi yang terbuat dari tepung ikan teri laut, tepung ubi jalar ungu dan tepung rumput laut dengan penambahan gliserol dengan katagori formula media 1 (tepung ikan teri laut 16,7 gram, tepung ubi jalar ungu 15 gram, Tepung Rumput Laut 1,5 gram, agar-agar 15 gram, Gliserol $12 \mathrm{ml}$, Aquadest $1000 \mathrm{ml}$ ), formula media 2 (Tepung Ikan Teri Laut 33,4 gram, tepung ubi jalar ungu 30 gram, tepung rumput laut 3 gram, agar-agar 15 gram, Gliserol $12 \mathrm{ml}$, Aquadest $1000 \mathrm{ml}$ ) dan formula media 3 (Tepung Ikan Teri Laut 50,1 gram, Tepung Ubi Jalar Ungu 45 gram, Tepung Rumput Laut 4,5 gram, agar-agar 15 gram, Gliserol $12 \mathrm{ml}$, Aquadest $1000 \mathrm{ml}$. Masing-masing campuran formula dimasukkan dalam beker glass dipanaskan sampai mendidih, dimasukkan dalam tabung ulir sebanyak $7 \mathrm{ml}$, disteril 121 derajat Celsius selama 15 menit, medium dimiringkan sampai membeku, selanjutnya dilakukan uji stabilitas medium sebelum digunakan.

Pembuatan media kontrol Loweinstein Jensen (LJ) 7245 dari Acumedia. Uji stabilitas media formulasi dilakukan dengan menginkubasi media dalam inkubator suhu $37^{\circ} \mathrm{C}$ selama 4 hari sebelum digunakan untuk pengujian. Hasil uji stabilitas media dilihat ada tidaknya pertumbuhan bakteri kontaminan. Jika tidak terdapat bakteri kontaminan media bisa digunakan. Pada pembuatan Kultur $M$. Tuberculosis yang digunakan adalah koloni $M$. Tuberculosis ATCC 25177 yang telah di kultur pada media LJ berumur 3-4 minggu.

Sebelum dilakukan inokulasi pada media formulasi penelitian, maka isolate $M$. Tuberculosis ATCC 25177 di homogenisasi pada media midlebrook $7 \mathrm{H} 9$ steril dalam tabung yang di dalamnya ditambahkan dengan glass beads steril sehingga pada saat homogenisasi koloni M. Tuberculosis ATCC 25177 tersebar merata. Homogenisasi dilakukan dengan divortex sampai homogen, kekeruhan suspensi M. Tuberculosis ATCC 25177 dibandingkan dengan standart kekeruhan 1 Unit Mc. Farland (pencampuran $\mathrm{BaCl}_{2} 1 \%$ sebanyak $1 \mathrm{ml}$ dan $\mathrm{H}_{2} \mathrm{SO}_{4} \quad 1 \%$ sebanyak $9 \mathrm{ml}$ ) jumlah sel $M$. Tuberculosis ATCC 25177 setara dengan 0,3 x $10^{9} / \mathrm{ml}$.

Suspensi M. Tuberculosis ATCC 25177 dimasukkan 1000 ul ke dalam masing-masing tabung media TURL dan Media kontrol LJ dan diinkubasi dalam incubator suhu $37^{\circ} \mathrm{C}$ dengan pengamatan maksimal selama 8 minggu sesuai standart dengan pengamatan pertumbuhan untuk perhitungan kecepatan tumbuh dan angka kesuburan setiap hari. Ciri morfologi koloni $M$. Tuberculosis adalah kasar, kering, rapuh, tengah bertumpuk dengan tepi berjejas tipis; 
kadang-kadang tipis dan menyebar, berwarna kuning muda (cream).

Untuk mendapatkan hasil kecepatan pertumbuhan $M$. Tuberculosis dan angka kesuburan pertumbuhan $M$. Tuberculosis dilakukan pengamatan setiap hari dengan batas waktu pengamatan maksimal 8 minggu. Jika dalam waktu 8 minggu tidak terdapat pertumbuhan $M$. Tuberculosis yang dibandingkan dengan medium kontrol Loweinstein-Jensen, maka dapat dinyatakan bahwa media TRULM tidak dapat digunakan untuk pertumbuhan M. Tuberculosis.

\section{Analisis Data}

Data dari hasil pengamatan kecepatan pertumbuhan koloni dan angka kesuburan pertumbuhan koloni $M$. Tuberculosis ATCC 25177 pada masing-masing media sederhana TRULM dan media kontrol LJ dianalisis secara deskriptif. Etik penelitian didapatkan dari komisi etik fakultas kedokteran Universitas Mataram.

\section{HASIL PENELITIAN \\ Data Kecepatan Pertumbuhan $M$. Tuberculosis ATCC 25177 pada Media TURLM (Teri Ubi Rumput Laut Medium) dan Media Kontrol Loweinstein-Jensen (LJ) Hasil pengamatan kecepatan pertumbuhan $M$. Tuberculosis pada media TURLM (Teri Ubi Rumput Laut Medium) dan media Kontrol Loweinstein-Jensen (LJ) dapat dilihat pada tabel 1.}

Tabel 1. Kecepatan Pertumbuhan Koloni M. Tuberculosis ATCC 25177 berdasarkan Waktu Inkubasi

\begin{tabular}{|c|c|c|c|c|c|}
\hline \multirow{2}{*}{ Media } & \multirow{2}{*}{ Ulangan } & \multicolumn{4}{|c|}{ Kecepatan Pertumbuhan M. Tuberculosis ATCC 25177} \\
\hline & & 1 s.d 4 hari & 5 s.d 6 hari & 7 s.d 9 hari & 10 s.d 14 hari \\
\hline \multirow{4}{*}{ TURLM FI } & 1 & - & - & - & + \\
\hline & 2 & - & - & - & + \\
\hline & 3 & - & - & - & + \\
\hline & 4 & - & - & - & + \\
\hline \multirow{4}{*}{ TURLM F2 } & 1 & - & - & + & + \\
\hline & 2 & - & - & + & + \\
\hline & 3 & - & - & + & + \\
\hline & 4 & - & - & + & + \\
\hline \multirow{4}{*}{ TURLM F3 } & 1 & - & + & + & + \\
\hline & 2 & - & + & + & + \\
\hline & 3 & - & + & + & + \\
\hline & 4 & - & + & + & + \\
\hline \multirow{4}{*}{ Kontrol LJ } & 1 & - & + & + & + \\
\hline & 2 & - & + & + & + \\
\hline & 3 & - & + & + & + \\
\hline & 4 & - & + & + & + \\
\hline \multicolumn{6}{|l|}{ Keterangan : } \\
\hline TURLM F2 & \multicolumn{5}{|c|}{ : Teri Ubi Rumput Laut Medium Formula 2} \\
\hline TURLM F3 & \multicolumn{5}{|c|}{ : Teri Ubi Rumput Laut Medium Formula 3} \\
\hline Kontrol LJ & \multicolumn{5}{|c|}{ : kontrol Loweinstein-Jensen } \\
\hline (negatif) & \multicolumn{5}{|c|}{ : belum terlihat pertumbuhan koloni M. Tuberculosis ATCC 25177} \\
\hline+ (positif) & \multicolumn{5}{|c|}{ : terlihat pertumbuhan koloni M. Tuberculosis ATCC 25177} \\
\hline
\end{tabular}

Tabel 1 menunjukkan hasil bahwa perbedaan komposisi dari media alternatif yang tersusun dari bahan alam tepung ikan teri, rumput laut dan ubi jalar ungu menunjukkan kecepatan waktu tumbuh dari M. Tuberculosis ATCC 25177 yang berbeda. Pengamatan kecepatan pertumbuhan dilakukan selama 14 hari, hari 1 sampai dengan ke 4 pada semua formula TURLM dan media standart LJ belum menunjukkan pertumbuhan koloni $M$. Tuberculosis ATCC 25177. Pertumbuhan baru terlihat pada hari ke 5 masa inkubasi. Hasil pertumbuhan M. Tuberculosis ATCC 25177 yang tercepat terdapat pada formula tiga 
(TURLM F3) yang kecepatan pertumbuhannya sama dengan media standart LoweinsteinJensen (LJ). Formula tiga dan media standart LJ menunjukkan hasil pertumbuhan positif sejak hari ke lima waktu inkubasi. Formula 2 baru menunjukkan pertumbuhan $M$. Tuberculosis ATCC 25177 pada hari ke-7 waktu inkubasi dan formula 1 pada hari ke 10 waktu inkubasi. Hasil pertumbuhan $M$. Tuberculosis ATCC 25177 yang paling lambat terdapat pada formula satu (TURLM F1).

Data Angka Kesuburan Pertumbuhan $M$. Tuberculosis ATCC 25177 pada Media TURLM (Teri Ubi Rumput Laut Medium) dan Media Kontrol Loweinstein- Jensen (LJ) Angka kesuburan pertumbuhan $M$. Tuberculosis ATCC 25177 diamati dari hari terlihat munculnya koloni M. Tuberculosis ATCC 25177 sampai hari batas maksimal besar koloni yang tumbuh (tidak pada koloni yang melebar), batas maksimum pengamatan angka kesuburan ini adalah 8 minggu. Angka Kesuburan Pertumbuhan meliputi :

1 = makroskopis tidak ada pertumbuhan, mikroskopis terdapat kuman tahan asam

2 = koloni lebih kecil dari kepala jarum

3 = koloni sebesar kepala jarum

4 = koloni sebesar $1 \times 1 \mathrm{~mm}^{3}$ atau lebih

(John Crofton; Norman Horne dan Fred Miller, 2002)

Adapun hasil pengamatan Angka kesuburan pertumbuhan M. Tuberculosis ATCC 25177 pada media TURLM (Teri Ubi Rumput Laut Medium) dan media Kontrol LoweinsteinJensen (LJ) dapat dilihat pada tabel 2.

Tabel 2 Angka Kesuburan Pertumbuhan Koloni M. Tuberculosis ATCC 25177 berdasarkan Waktu Inkubasi

\begin{tabular}{|c|c|c|c|c|c|c|c|c|}
\hline \multirow{2}{*}{ Media } & \multirow{2}{*}{ Ulangan } & \multicolumn{7}{|c|}{$\begin{array}{c}\text { Angka Kesuburan Pertumbuhan M. Tuberculosis ATCC } 25177 \text { Minggu I } \\
\text { (Pertama) }\end{array}$} \\
\hline & & $\begin{array}{l}1 \text { s.d } 4 \\
\text { hari }\end{array}$ & $\begin{array}{l}5 \text { s.d } 6 \\
\text { hari }\end{array}$ & $\begin{array}{c}7 \text { s.d } 9 \\
\text { hari }\end{array}$ & $\begin{array}{l}10 \text { s.d } 14 \\
\text { hari }\end{array}$ & $\begin{array}{l}15 \text { s.d } 21 \\
\text { hari }\end{array}$ & $\begin{array}{l}22 \text { s.d } 27 \\
\text { hari }\end{array}$ & $\begin{array}{c}24 \text { s.d } 34 \\
\text { hari }\end{array}$ \\
\hline \multirow{4}{*}{ TURLM FI } & 1 & 1 & 1 & 1 & 2 & 2 & 1 & 1 \\
\hline & 2 & 1 & 1 & 1 & 2 & 2 & 1 & 1 \\
\hline & 3 & 1 & 1 & 1 & 2 & 1 & 1 & 1 \\
\hline & 4 & 1 & 1 & 1 & 2 & 1 & 1 & 1 \\
\hline \multirow{4}{*}{ TURLM F2 } & 1 & 1 & $\overline{1}$ & 2 & 2 & 1 & 1 & 2 \\
\hline & 2 & 1 & 1 & 2 & 2 & 1 & 1 & 2 \\
\hline & 3 & 1 & 1 & 2 & 2 & 1 & 1 & 2 \\
\hline & 4 & 1 & 1 & 2 & 2 & 1 & 1 & 2 \\
\hline \multirow{4}{*}{ TURLM F3 } & 1 & 1 & 2 & 2 & 3 & 2 & 2 & 2 \\
\hline & 2 & 1 & 2 & 2 & 3 & 2 & 2 & 2 \\
\hline & 3 & 1 & 2 & 2 & 3 & 2 & 2 & 2 \\
\hline & 4 & 1 & 2 & 2 & 3 & 2 & 2 & 2 \\
\hline \multirow{4}{*}{ Kontrol LJ } & 1 & $\overline{1}$ & 2 & 2 & 3 & 2 & 2 & 2 \\
\hline & 2 & 1 & 2 & 2 & 3 & 2 & 2 & 2 \\
\hline & 3 & 1 & 2 & 2 & 3 & 2 & 2 & 2 \\
\hline & 4 & 1 & 2 & 2 & 3 & 2 & 2 & 2 \\
\hline \multicolumn{9}{|l|}{ Keterangan : } \\
\hline TURLM F1 & \multicolumn{8}{|c|}{ : Teri Ubi Rumput Laut Medium Formula 1} \\
\hline TURLM F2 & \multicolumn{8}{|c|}{ : Teri Ubi Rumput Laut Medium Formula 2} \\
\hline TURLM F3 & \multicolumn{8}{|c|}{ : Teri Ubi Rumput Laut Medium Formula 3} \\
\hline Kontrol LJ & \multicolumn{8}{|c|}{ : kontrol Loweinstein-Jensen } \\
\hline - (negatif) & \multirow{2}{*}{\multicolumn{8}{|c|}{ : belum terlihat pertumbuhan Koloni M. Tuberculosis ATCC 25177}} \\
\hline$+($ positif $)$ & & & & & СC 25177 & & & \\
\hline
\end{tabular}

Tabel 2 menunjukkan hasil angka kesuburan pertumbuhan M. Tuberculosis ATCC 25177 dengan lama waktu inkubasi maksimal 8 minggu (34 hari). Hari 1 sampai dengan hari ke 4 angka kesuburan pertumbuhan $M$. Tuberculosis ATCC 25177 pada semua formula media TURLM dan media standart LJ menunjukkan angka 1 yang artinya secara mikroskopis positif BTA namun secara makroskopis belum terlihat adanya koloni pertumbuhan M. Tuberculosis ATCC 25177. 
Angka kesuburan pertumbuhan $M$. Tuberculosis ATCC 25177 yang paling baik ditunjukkan pada pertumbuhan di media TURLM formula 3 yang menunjukkan hasil sama dengan media standar LJ. Angka kesuburan pertumbuhan pada formula TURLM 3 pada hari ke 5 s.d 7 adalah 2 yang artinya koloni lebih kecil dari kepala jarum, hari ke 8 sampai dengan ke 14 adalah 3 yang artinya koloni sebesar kepala jarum dan hari ke 15 sampai dengan 34 adalah 4 yang artinya koloni sebesar 1 x $1 \mathrm{~mm}^{3}$ atau lebih. Angka kesuburan pertumbuhan M. Tuberculosis ATCC 25177 yang paling lambat terdapat pada formula 1 .

\section{PEMBAHASAN}

Karakteristik pertumbuhan $M$. Tuberculosis merupakan bakteri aerob obligat dan memperoleh energi dari oksidasi banyak senyawa karbon sederhana. Peningkatan tekanan $\mathrm{CO}_{2}$ akan meningkatkan pertumbuhan $M$. Tuberculosis. Aktifitas biokimia $M$. Tuberculosis tidak khas, dan kecepatan pertumbuhan M. Tuberculosis jauh lebih lambat dari pada sebagian besar bakteri. Waktu pembelahan basil tuberculosis adalah sekitar 18 jam. Sifat $M$. Tuberculosis yang lambat pada waktu pembelahan menyebabkan koloni pada kultur pertumbuhan umumnya baru tampak setelah 4 s.d 8 minggu pertumbuhan.

Kultur M. Tuberculosis dari dahak penderita merupakan gold standart untuk menegakkan diagnose TB. Media yang umum digunakan adalah media Loweinstein-Jensen (LJ) dan Ogawa medium yang mengandung mineral, elektrolit, protein dari suspense telur, karbohidrat dari tepung kentang, dan malacit green untuk menghambat pertumbuhan bakteri lain direkomendasikan sebagai isolasi, kultur dan studi kerentanan terhadap obat. Pertumbuhan pada media LJ dan Ogawa akan timbul koloni antara waktu minggu ke 2 sampai minggu ke 6 dan batas pengamatan maksimal sampai minggu ke 8. Media standar LJ dan Ogawa relative mahal, sehingga dalam penelitian ini mengali beberapa sumber bahan alam yang mudah ditemukan di masyarakat, yang harganya relatif murah sebagai bahan dasar dalam pembuatan media untuk pertumbuhan $M$. Tuberculosis seperti pengembangan formula Tepung Teri Laut, Ubi jalar ungu dan rumput laut yang dalam penelitian ini dinamakan media TURLM.
Hasil penelitian untuk identifikasi kecepatan pertumbuhan $M$. Tuberculosis dilihat dengan mulai munculnya koloni $M$. Tuberculosis pada media TRULM dan LJ sebagai media pembanding (kontrol) menunjukkan bahwa hasil kecepatan pertumbuhan M. Tuberculosis ATCC 25177 pada media TURLM dan media kontrol LJ yang diamati perhari pada minggu I (pertama). Pada media TURLM Formula 1 pada minggu pertama sampai hari ke-7 belum menunjukkan adanya pertumbuhan koloni $M$. Tuberculosis ATCC 25177, pertumbuhan koloni baru terlihat pada media TURLM Formula 2 pada hari ke -7, dan TURLM formula 3 pada hari ke-5 dengan ciri pertumbuhan koloni cirri morfologi koloni M. Tuberculosis bulat, sedikit kasar, kering, rapuh, tengah bertumpuk dengan tepi berjejas tipis; kadang-kadang tipis dan menyebar, berwarna coklat keruh. Pertumbuhan koloni pada media kontrol LJ juga terlihat pertumbuhan mulai pada hari ke-5, dengan ciri morfologi koloni M. Tuberculosis adalah sebagai berikut: kasar, kering, rapuh, tengah bertumpuk dengan tepi berjejas tipis; kadangkadang tipis dan menyebar, berwarna kuning muda (cream).

Hasil pengamatan pada minggu II (kedua) terlihat kecepatan pertumbuhan media TURLM Formula 1 pada minggu kedua mulai menunjukkan pertumbuhan koloni $M$. Tuberculosis ATCC 25177 pada hari ke-10, sedangkan pada media media TURLM Formula 2, TURLM formula 3 dan media LJ menunjukkan pertumbuhan koloni yang semakin banyak dan besar. Hasil penelitian ini membuktikan bahwa dari formulasi media TURLM ketiga formula menunjukkan kemampuan dalam menumbuhkan $M$. Tuberculosis ATCC 25177, dengan hasil kecepatan yang terbaik pada formula TURLM 3 yang hasil kecepatan pertumbuhannya sama dengan media standart LJ. Kemampuan menumbuhkan M. Tuberculosis ATCC 25177 disebabkan karena sumber bahan pembuatan media dapat menggantikan karbohidrat, protein, mineral serta elektrolit yang terdapat pada media LJ. Komposisi Tepung ikan teri, tepung ubi jalar ungu dan tepung rumput laut dapat memenuhi kebutuhan nutrisi $M$. Tuberculosis, karena pada Ikan Teri adalah bahan makanan hewani laut yang biasa dikonsumsi oleh masyarakat Indonesia. Ikan Teri mengandung energi sebesar 74 kilo kalori, protein 10,3 gram, 
karbohidrat 4,1 gram, lemak 1,4 gram, kalsium 972 miligram, fosfor 253 miligram, dan zatbesi 3,9 miligram. Selain itu di dalam Ikan Teri juga terkandung vitamin A sebanyak 42 IU, vitamin B1 0,24 miligram dan vitamin $\mathrm{C} 0$ miligram. Hasil tersebut didapatkan dari melakukan penelitian terhadap 100 gram Ikan Teri, dengan jumlah yang dapat dimakan sebanyak $100 \%$.

Informasi rinci komposisi kandungan nutrisi/gizi pada ikan teri yaitu bahwa banyaknya ikan teri yang diteliti (Food Weight) $=100$ gr, bagian ikan teri yang dapat dikonsumsi $($ Bdd/Food Edible $)=100 \%$ kandungannya adalah Energi Ikan Teri $=74$ kkal, jumlah kandungan protein ikan teri $=10,3$ gr, lemak ikan teri $=1,4 \mathrm{gr}$, karbohidrat ikan teri $=4,1 \mathrm{gr}$, kalsium ikan teri $=972 \mathrm{mg}$, fosfor ikan teri $=253 \mathrm{mg}$, zat besi ikan teri $=3,9 \mathrm{mg}$, vitamin a ikan teri $=42 \mathrm{iu}$, vitamin b1 ikan teri $=0,24 \mathrm{mg}$, vitamin $\mathrm{c}$ ikan teri $=0 \mathrm{mg}$ (Fahmi, A 2012; Wiwit, P.2015).

Ubi jalar ungu mengandung pigmen anthosianin yang lebih tinggi daripada ubi jalar jenis lain. Pigmennya lebih stabil bila dibandingkan anthosianin dari sumber lain seperti kubis merah, elderberries, bluberries dan jagung merah. Komposisi kimia ubi jalar adalah air $50-81 \%$, protein $1-2,45$,lemak 1,8 $-6,4 \%$, karbohidrat $8-29 \%$, gula pereduksi $0,5-7,5 \%$, abu $0,9-1,4 \%$, tiamin $0,1 \%$, asam Askorbat $25 \mathrm{gr} / 100 \mathrm{~g}$ dan riboflavin 0,06\%. Kandungan nutrisi ubi jalar ungu lebih tinggi bila dibandingkan ubi jalar varietas lain, terutams kandungan lisin, $\mathrm{Cu}, \mathrm{Mg}, \mathrm{K}, \mathrm{Zn}$ ratarata $20 \%$. Ubi jalar merupakan sumber karbohidrat dan sumber kalori yang cukup tinggi. Ubi jalar juga merupakan sumber vitamin dan mineral, vitamin yang terkandung dalam ubi jalar antara lain vitamin A, vitamin C, thiamin (vitamin B1) dan ribovlavin. Sedangkan mineral dalam ubi jalar di antaranya adalah zat besi $(\mathrm{Fe})$, fosfor $(\mathrm{P})$, dan kalsium (Ca).

Kandungan lainnya adalah protein, lemak, serat kasar dan abu. Total kandungan antosianin bervariasi pada setiap tanaman dan berkisar antara $20 \mathrm{mg} / 100 \mathrm{~g}$ sampai 600 $\mathrm{mg} / 100 \mathrm{~g}$ berat basah. Total kandungan antosianin ubi jalar ungu adalah $519 \mathrm{mg} / 100 \mathrm{~g}$ berat basah (Kumalaningsih, 2007; Hardoko Liana H, dan Tagor, M. 2010). Kandungan kimia dari rumput laut Eucheuma spinosum adalah keraginan (65\%), protein, karbohidrat, lemak, seratkasar, air dan abu. Keraginan merupakan polisakarida tersulfatkan dimana kandungan ester sulfatnya adalah 28$35 \%$. Komposisi kimia yang dimiliki rumput laut Eucheuma spinosum yaitu Komposisi Kadar air 21,90 (\%) Protein 5,12 (\%) Lemak $0,13(\%) \quad$ Karbohidrat 13,38 (\%) Serat kasar 1,39 (\%) Abu 14,21 (\%) Mineral 52,85 ppm $\mathrm{Ca} 0,180$ ppm Fe, 768 ppm Cu 0,21 mg/100g Pb $2,26 \mathrm{mg} / 100 \mathrm{~g}$ Vit B43 mg/100g, (Thiamin) Vit B dan (Ribolavin) Vit C (Horboruw, 2012; Suparmi \& Sahri, 2009). Komposisi media alam yang kaya akan karbohidrat, protein dan mineral sangat potensial untuk alternatif media pertumbuhan $M$. tuberculosis, seperti yang terdapat pada formula media TURLM dalam penelitian ini.

Penelitian ini juga sejalan dengan penelitian Anisful L tahun 2015 yang mencari bahan alam yang kaya protein dan mineral seperti media yang dihasilkan dalam penelitiannya yaitu media Coco Blood Malachite Green (CMB) dengan menggunakan air kelapa dari jenis kelapa Cocos nucifera dan serbuk agar darah yang membuktikan kecepatan pertumbuhan $M$. Tuberculosis lebih cepat dari media LJ. Kebaharuan dari hasil penelitian ini yang membedakannya dengan penelitian penelitian tentang eksplorasi bahan alam untuk pertumbuhan $M$. Tuberculosis adalah belum ada penelitian yang mengeksplorasi bahan alam dari kombinasi tepung ikan teri, rumput laut dan ubi jalar ungu sebagai alternatif media pertumbuhan M. Tuberculosis.

Angka kesuburan pertumbuhan $M$. tuberculosis ATCC 25177 merupakan koloni yang tumbuh pada medium pertumbuhan dengan mengamati dari terlihat munculnya koloni M. Tuberculosis ATCC 25177 sampai hari batas maksimal besar koloni yang tumbuh (tidak pada koloni yang melebar), batas maksimum pengamatan angka kesuburan ini adalah 8 minggu. Hasil penelitian membuktikan bahwa pada media TURLM (Teri Ubi Rumput Laut Medium) dan media Kontrol LoweinsteinJensen (LJ) yang diamati perhari pada minggu I (pertama). Pada media TURLM Formula 1 sampai hari ke-7 pada minggu pertama menunjukkan angka kesuburan 1 karena secara makroskopis tidak ada pertumbuhan, mikroskopis terdapat Bakteri Tahan Asam (BTA) M. Tuberculosis ATCC 25177, sedangkan pada media media TURLM Formula 2 angka kesuburan pertumbuhan pada hari ke 1 
sampai dengan ke 6 adalah angka kesuburan 1, mulai hari ke-7 pada pengamatan minggu I angka kesuburannya 2 yaitu sudah muncul koloni yang besarnya lebih kecil dari kepala jarum. Pada TURLM formula 3 dan media LJ menunjukkan angka kesuburan pertumbuhan 1 pada hari ke 1 sampai dengan hari ke 4, sedangkan pada hari ke 5 sudah mulai muncul koloni dengan angka kesuburan pertumbuhan 2 sampai pengamatan pada hari ke-7 pada minggu pertama.

Hasil angka kesuburan pertumbuhan $M$. Tuberculosis ATCC 25177 pada media TURLM dan media kontrol LJ yang diamati perhari pada minggu II (kedua) adalah pada media TURLM Formula 1 menunjukkan angka kesuburan 1 pada hari ke 8 dan ke 9 karena secara makroskopis tidak ada pertumbuhan, mikroskopis terdapat Bakteri Tahan Asam (BTA) M. Tuberculosis ATCC 25177, mulai hari ke 10 sampai dengan hari ke 14 menunjukkan angka kesuburan 2 karena sudah muncul koloni M. Tuberculosis ATCC 25177 dengan ukuran lebih kecil dari kepala jarum, sedangkan pada media media TURLM Formula 2 angka kesuburan pertumbuhan pada hari ke 8 sampai dengan ke 14 adalah angka kesuburan 2. Pada TURLM formula 3 dan media LJ menunjukkan angka kesuburan pertumbuhan 3, dimana koloni yang tumbuh sebesar kepala jarum mulai hari ke 8 sampai dengan pada hari ke 14.

Hasil angka kesuburan pertumbuhan $M$.

Tuberculosis ATCC 25177 pada media TURLM dan media kontrol LJ yang diamati perhari pada minggu III (tiga). Pada media TURLM formula 1 menunjukkan angka kesuburan konstan (tetap) pada hari ke 15 sampai dengan 21 yaitu angka kesuburan pertumbuhan 2, sedangkan pada media TURLM formula 2 angka kesuburan pertumbuhan pada hari ke 15 sampai dengan ke 21 adalah angka kesuburan 3. Pada TURLM formula 3 dan media LJ menunjukkan angka kesuburan pertumbuhan 4 yaitu koloni yang tumbuh lebih besar dari kepala jarum. Hasil angka kesuburan pertumbuhan $M$. Tuberculosis ATCC 25177 pada media TURLM dan media kontrol LJ yang diamati perhari pada minggu IV (empat). Pada media TURLM formula 1 menunjukkan angka kesuburan konstan (tetap) pada hari ke 21 sampai dengan 27 yaitu angka kesuburan pertumbuhan 2, pada media TURLM formula 2 angka kesuburan pertumbuhan pada hari ke 21 sampai dengan ke 27 adalah konstan (tetap) adalah angka kesuburan 3. Pada TURLM formula 3 dan media LJ menunjukkan angka kesuburan pertumbuhan 4 pada pengamatan hari ke 21 sampai dengan 27 pada minggu ke IV (empat) adalah konstan (tetap) yaitu koloni yang tumbuh lebih besar dari kepala jarum. Hasil angka kesuburan pertumbuhan M. Tuberculosis ATCC 25177 pada media TURLM dan media kontrol LJ yang diamati perhari pada minggu V (lima).

Pada media TURLM formula 1 menunjukkan angka kesuburan konstan (tetap) pada hari ke 28 sampai dengan 34 yaitu angka kesuburan pertumbuhan 2, pada media TURLM formula 2 angka kesuburan pertumbuhan pada hari ke 28 sampai dengan ke 38 adalah konstan (tetap) adalah angka kesuburan 3. Pada TURLM formula 3 dan media LJ menunjukkan angka kesuburan pertumbuhan 4 pada pengamatan hari ke 28 sampai dengan 38 pada minggu ke V (lima) adalah konstan (tetap) yaitu koloni yang tumbuh lebih besar dari kepala jarum. Karena pada minggu ke V (lima) pertumbuhan tetap, tidak terjadi perkembangan angka kesuburan pertumbuhan $M$. Tuberculosis ATCC 25177 oleh sebab itu maka pengamatan angka kesuburan pertumbuhan sampai pada minggu ke $\mathrm{V}$ (lima).

Hasil penelitian ini menunjukkan bahwa media TURLM baik formula 1,2 dan 3 memiliki kemampuan dalam pertumbuhan $M$. Tuberculosis, dengan kecepatan pertumbuhan dan angka kesuburan yang terbaik adalah pada formula TRULM 3. Walaupun hasil kecepatan pertumbuhan dan angka kesuburan pertumbuhan yang dihasilkan dari media formula TURLM baik, tetapi media ini memiliki kelemahan yaitu tidak bisa digunakan untuk inokulasi M. Tuberculosis pada plate karena rentan dengan kontaminasi jamur, hal ini terbukti dengan beberapa kali penelitian pertumbuhan menggunakan plate hasilnya terkontaminasi oleh jamur jenis Aspergillus $S p$, sehingga pembiakan menggunakan tabung reaksi 20cc atau tabung reaksi ulir, sesuai standar tempat media pertumbuhan $M$. Tuberculosis sehingga perlu dipikirkan cara modifikasi medium TURLM dengan menambahkan bahan-bahan selektif yang dapat menghambat pertumbuhan jamur dan bakteri kontaminan. Kelemahan lain dari penelitian ini adalah tidak diketahui pola sensitivitas dan spesifisitas media formula TURLM baik dari 
segi kecepatan pertumbuhan maupun dari angka kesuburan.

\section{KESIMPULAN DAN SARAN}

Media formulasi kombinasi pangan lokal TURLM (Teri Ubi Rumpu Laut Medium) formula 3 dapat mempercepat pertumbuhan dan angka kesuburan pertumbuhan $M$. Tuberculosis ATCC 25177. Disarankan agar dilakukan studi lanjutan dengan melakukan penelitian tentang pola spesifisitas dan sensitivitas media TURLM Formula 3 dengan pembanding media Loweinstein-Jensen menggunakan sampel dahak dari penderita TBC. Menggunakan jumlah sampel yang representatif dan studi lanjutan dengan melakukan penelitian modifikasi komposisi media TURLM dengan penambahan zat-zat selektif untuk mencegah pertumbuhan bakteri kontaminan dan jamur.

\section{DAFTAR PUSTAKA}

Anisful LM, Hidayati DYN dan Utami YW, 2015. Studi Komparasi media kulturCoco Blood malachite Green (CBM) dengan Loweinstein-Jensen (LJ) untuk Diagnostik cepat, Spesifik, dan Sensitif pada Sputum Pasien Suspek Tuberculosis. Majalah kesehatan FKUB.

Crofton, S. J., Horne, N., \& Miller, F. (2002). Tuberkulosis Klinis. Jakarta: Widya Medika.

Fahmi, A. (2012). Kadar protein dan Ca pada Ikan Teri Asin Hasil Pengasinan dengan Abu Pelepah Kelapa. Surakarta: Naskah Publikasi Fakultas Keguruan dan Ilmu Pendidikan Universitas Muhammadiyah Surakarta.

Hardoko Liana H, \& Tagor, M. (2010). Pemanfaatan Ubi Jalar Ungu (Ipomoea batatas L.PoirO sebagai pengganti Sebagian Tepung Terigu dan sumber Antioksidan pada Roti Tawar. J.Teknol dan Industri Pangan,Vol.XXI No.1 (pp.
25-32). pp. 25-32.

Horboruw, M. W. (2012). Kandungan Iodium Telur Pertama Ayam Fast Pullet yang diberi Pakan Rumput Laut (Gracillaria edulisd). Agrinimal (Jurnal Ilmu Ternak dan Tanaman), Volume 2 N, 79-90.

Kumalaningsih, S. (2007). Antioksidan Alami Penangkal Radikal Bebas. Surabaya: Trubus Agrisarana.

Munawaroh, A. L., Hidayati, D. Y. N., \& Utami, Y. W. (2015). Studi Komparasi Media Kultur Coco Blood Malachite Green (CBM) dengan Lowenstein Jensen (LJ) untuk Diagnosis Cepat, Spesifik, dan Sensitif pada Sputum Pasien Suspek Tuberkulosis. Majalah Kesehatan FKUB, 2, 79-91.

Maria. N \& Rosnita, S. (2018). Pengaruh Pemberian Air Kelapa (Cocos nucifera. L) pada Media Agar Darah terhadap Pertumbuhan Bakteri Mycobacterium Tuberculosis. Jurnal Kesehatan Volume 9, Nomor 3.

Patrick R. Murray, \& Rosenthal, K. S. (2007). Buku Ajar Mikrobiologi. Jakarta: Penerbit Buku Kedokteran EGC.

Srigede, L., Zaetun, S., \& Getas, I. W. (2013). Perbedaan Pertumbuhan Mycobacterium tuberculosis pada Media Agar Nutrien dengan Penambahan Tepung Cacing (Lumbricus rubellous) dibandingkan dengan Pertumbuhan pada Media Loweinstein Jensen. Media Bina Ilmiah, 7(5), 36-42.

Suparmi, \& Sahri, A. (2009). Mengenal Potensi Rumput Laut: Kajian Pemanfaatan Sumber Daya Rumput Laut dari Aspek Industri dan Kesehatan. Sultan Agung Volume XILIV No 118, 95-116.

Wiwit, P. (2015). Kandungan Kadar Protein dan Air dalam Ikan Teri (Stolephorus Sp) Asin dengan Oven sebagai alternative Pengganti Panas Matahari. 